Article

\title{
Inhalation Exposure to Gaseous and Particulate Bound Mercury Present in the Ambient Air over the Polluted Area of Southern Poland
}

\author{
Halina Pyta ${ }^{\mathbb{D}}$, Kamila Widziewicz-Rzońca * and Krzysztof Słaby ${ }^{\mathbb{D}}$ \\ Institute of Environmental Engineering Polish Academy of Sciences, M. Skłodowskiej-Curie 34 St., \\ 41-819 Zabrze, Poland; halina.pyta@ipis.zabrze.pl (H.P.); krzysztof.slaby@ipis.zabrze.pl (K.S.) \\ * Correspondence: kamila.widziewicz@ipis.zabrze.pl
}

Received: 1 June 2020; Accepted: 7 July 2020; Published: 11 July 2020

check for updates

\begin{abstract}
This study concerns the concentrations of gaseous and particle-bound mercury present in ambient air of two Polish sites, differing in terms of emission structure, and the estimation of inhalation risks related to those $\mathrm{Hg}$ species. The measurements of total gaseous mercury (TGM) and $\mathrm{PM}_{2.5}$-bound mercury (PBM) were performed at an urban station in Zabrze and a rural station in Złoty Potok, in 2014-2015. Both sites are located in Silesia, considered one of the European air pollution hot-spots. TGM was measured on-line (Tekran 2537). $\mathrm{PM}_{2.5}$ samples were taken with the use of low volume samplers. Hg contents in PM were determined by the CVAAS method following thermal decomposition. The median concentrations of TGM and PBM in Zabrze were $2.48 \mathrm{ng} \mathrm{m}^{-3}$ and $37.87 \mathrm{pg} \mathrm{m}^{-3}$, respectively; meanwhile in Zloty Potok, these were $1.69 \mathrm{ng} \mathrm{m}^{-3}$ and $27.82 \mathrm{pg} \mathrm{m}^{-3}$, respectively. Clearly, seasonal variability of TGM and PBM concentrations were observed, reflecting the importance of $\mathrm{Hg}$ and PM emissions from coal combustion for power and heating purposes. Health risk assessment was performed using a deterministic approach by the most conservative exposure scenario. The obtained HQ ratios and the cumulative $\mathrm{HI}$ indexes were below the limit value $(<1)$. This means an unlikely health hazard due mercury inhalation.
\end{abstract}

Keywords: mercury; TGM; PBM; $\mathrm{PM}_{2.5}$; urban background; rural background; inhalation toxicity; exposure rate

\section{Introduction}

Mercury $(\mathrm{Hg})$ is a naturally occurring element found in the environment in inorganic form (I $\mathrm{Hg}$; elemental mercury $\mathrm{Hg}^{0}$, in liquid and gaseous state, and as numerous mercury salts, e.g., mercuric chloride $\mathrm{HgCl}_{2}$ ), and organic compounds (mostly short-chain alkyl derivatives, e.g., methylmercury $\mathrm{MeHg}$ ). I $\mathrm{Hg}$ can undergo methylation by biota mainly in aquatic environment and then bioaccumulation and biomagnification in food webs. Mercury is persistent in the environment. It cycles among the air, ocean, land, and biosphere [1]. Once released to the atmosphere, it can be transported over long distances and deposited on the Earth's surface even in remote areas, leading to contamination of aquatic and terrestrial ecosystems [2]. Although the atmosphere is a small reservoir of $\mathrm{Hg}$, relative to oceans and lands, it is viewed as the main pathway for the global cycling of mercury. Atmospheric $\mathrm{Hg}$ is currently measured as three operationally defined forms: gaseous elemental $\mathrm{Hg}$ $\left(\mathrm{Hg}^{0}, \mathrm{GEM}\right)$, gaseous oxidized $\mathrm{Hg}(\mathrm{GOM})$, with the sum of GEM and GOM designated as total gaseous mercury (TGM), and particulate bound $\mathrm{Hg}(\mathrm{PBM})$. The main form of atmospheric $\mathrm{Hg}$ is relatively chemically inert $\mathrm{Hg}^{0}$, which can remain in the air for up to a year [3]. $\mathrm{Hg}^{0}$ generally comprises more than $95 \%$ of total airborne $\mathrm{Hg}[4,5]$ and is fairly uniformly distributed in the Northern Hemisphere, with a range of concentrations of $1.3 \mathrm{v}-1.7 \mathrm{ng} \mathrm{m}^{-3}$ [6]. The concentrations of GOM and PBM (usually 
expressed in $\mathrm{pg} \mathrm{m}^{-3}$ ) are much lower than $\mathrm{Hg}^{0}$, they are essential for removing of mercury from the air by wet and dry deposition [5]. All $\mathrm{Hg}$ forms can derive from a multitude of natural and anthropogenic sources, both primary and secondary [7,8]. The latest estimates on $\mathrm{Hg}$ emissions of natural origin, including primary processes and re-emissions, were assessed to be $5207 \mathrm{Mg} \mathrm{yr}^{-1}$ [9]. The major anthropogenic sources of mercury, on a global scale, are artisanal and small-scale gold mining, combustion of fossil fuels for power and heat generation, industry of non-ferrous metals, cement production and large-scale gold production [10]. According to the AMAP/UNEP inventory, the global anthropogenic emission has been estimated to $1960 \mathrm{Mg} \mathrm{yr}^{-1}$ [8] and is a main factor disrupting the natural $\mathrm{Hg}$ cycling.

Mercury is considered as one of the top 10 chemicals of major public health concern by the World Health Organization (WHO) [11,12]. Toxicity of this element varies with its chemical form and the dose, as well as the route of exposure, the exposure duration, and individual vulnerability of the person exposed [13]. For mercury, the most sensitive subpopulations are developing organisms of the fetus, the newborn, and young children [12].

The respiratory tract is the main absorption route for both atmospheric mercury forms: TGM (mainly $\mathrm{Hg}^{0}$ ) and PBM (mainly $\mathrm{Hg}^{2+}$ and $\mathrm{Hg}^{+}$). Exposure to PBM may partly occur through the gastrointestinal system. Only $0.01 \%$ of $\mathrm{Hg}^{0}$ that reaches the gastrointestinal tract is absorbed, because of its conversion to $\mathrm{Hg}^{2+}$ and binding to sulfhydryl groups [7]. As much as $85 \%$ of the inhaled dose of $\mathrm{Hg}^{0}$ can be absorbed into the bloodstream and then distributed throughout the body [11,14]. After oxidation to $\mathrm{Hg}^{2+}$ via the hydrogen peroxide-catalase pathway [15], it easily binds to intra-cellular molecules $[13,16]$. Elemental mercury is toxic to the central and peripheral nervous system. It can cause neurological and behavioral disorders, such as tremors, neuromuscular effects, polyneuropathy, emotional changes, insomnia, memory loss, headaches, and cognitive and motor dysfunction. Long-term exposure to higher $\mathrm{Hg}^{0}$ levels $\left(>20 \mu \mathrm{g} \mathrm{m}^{-3}\right)$ may lead to changes in renal function and irritation of the respiratory tract [15]. There are only very few data available on the effects of inhalation of $\mathrm{I} \mathrm{Hg}$ compounds $\left(\mathrm{Hg}^{2+}, \mathrm{Hg}^{+}\right)$[17]. Quantitative information on these effects on humans is essentially not-existant [7]. The available reports suggest that absorption of I Hg may occur after inhalation or ingestion of dusts [16]. It is thought that I Hg absorption via the lungs is low, due to deposition of coarse particles in the upper respiratory tract and subsequent mucociliary clearance $[7,18]$. However Clarkson [19] reported absorption in dogs to be $40 \%$ via inhalation of $\mathrm{HgCl}_{2}$. Monovalent mercury compounds have limited solubility, so their absorption is less likely than for hydrophilic divalent forms [18]. Absorbed divalent cation from exposure to $\mathrm{Hg}^{2+}$ compounds can be reduced and released as elemental mercury vapor [15]. Inorganic mercury may damage the peripheral nervous system and lead to nephrotic syndrome in humans [15]. Boffetta and co-authors [20] found that chronic occupational exposure to I $\mathrm{Hg}$ was significantly associated with hypertension, heart diseases other than ischaemic, pneumoconiosis, nephritis, and nephrosis.

The International Agency for Research on Cancer concluded that mercury (CAS No. 7439-97-6) is not classified as carcinogenic to humans (Group 3) [21].

Inhalation exposure to $\mathrm{Hg}$ and its compounds is common. However, there is still insufficient information on the potential effects of long-term exposure to atmospheric mercury, depending on its chemical or physical form. Therefore, in this study, we tried to estimate the combined health risk posed by atmospheric mercury in gaseous form (TGM) and bound to $\mathrm{PM}_{2.5}$ (respirable fraction of particulates with diameters $\leq 2.5 \mu \mathrm{m}$ ), based on the methodology recommended by the U.S. Environmental Protection Agency (EPA). The potential health risk from inhalation of the both mercury forms was evaluated by using the hazard quotient (non-cancer outcome). We compared the hazard quotients for two Polish areas (urban and rural background), differing in terms of emission structure and mercury concentrations in the air. The assessment of such risks was done over 2-year measurement campaign (January 2014-December 2015) performed in Silesia Province, the most polluted region in Poland. Poland is the country with the highest $\mathrm{Hg}$ emissions in the European Union [22]. Following the Poland's Informative Inventory Report 2017 [23], these emissions were 9.6 and 10.6 Mg in 2014 and 2015, 
respectively. In 2015, about $94 \%$ of Polish anthropogenic emissions of $\mathrm{Hg}$ came from fuel combustion (mostly-hard coal) in heat and power industry (50\%), industrial power plants (35\%), and residential heating $(9 \%)$.

\section{Study Area}

The measurements were conducted at two sampling locations-Zabrze and Złoty Potok-in Silesian Province, a region greatly impacted by the industrial and municipal emissions in Southern Poland (Figure 1).

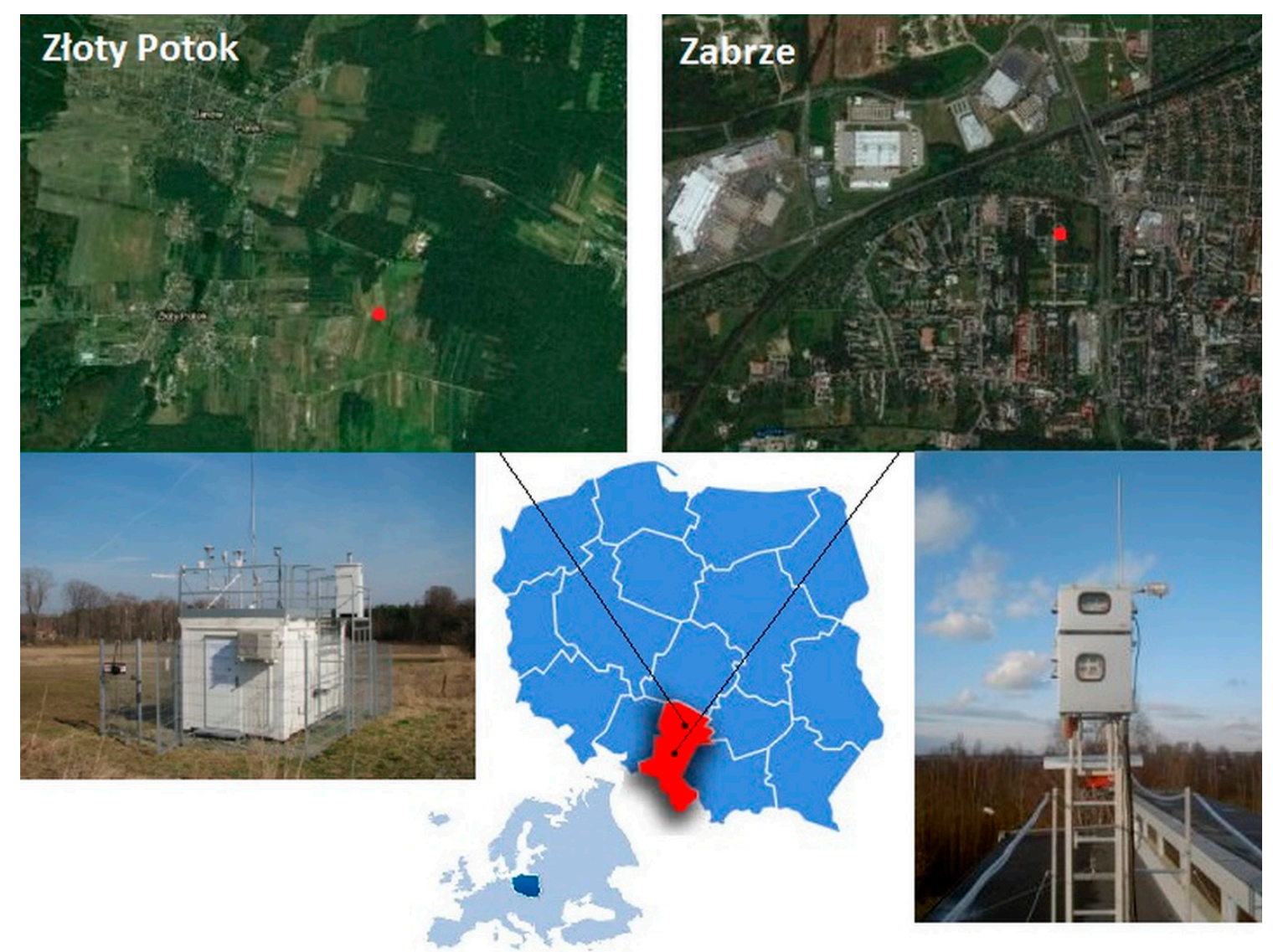

Figure 1. The location of measuring stations in Zabrze and Złoty Potok.

Zabrze (180,000 inhabitants) is one of the 14 cities which together make up the Upper Silesian Agglomeration (2 million inhabitants) in the central part of Silesian Province. Silesia is one of the European air pollution "hot-spots". This is a region where the risk of high air contamination of mercury occurs as a result of high anthropogenic emissions (Figure 2). Zabrze has the least developed central heating system in the entire agglomeration, most detached houses being individually heated by hard coal combustion. There are two cokeries and several coal fired heat and power plants within the city and in its close vicinity. The measurements were performed in the residential district of Zabrze, within the Institute of Environmental Engineering (IEE). The gaseous mercury sampling point was situated about $14 \mathrm{~m}$ above the ground and $1.7 \mathrm{~m}$ above the roof of two-storey IEE' building. Its geographical coordinates (WGS84) were as follows: $\varphi=50^{\circ} 18^{\prime} 59^{\prime \prime} \mathrm{N}, \lambda=18^{\circ} 46^{\prime} 18^{\prime \prime} \mathrm{E}$. There is also an automatic station of air quality monitoring located approximately $70 \mathrm{~m}$ from the IEE building and operated by the Regional Inspectorate for Environmental Protection (RIEP, http://powietrze.katowice.wios.gov.pl/stacje/stacja/5). The samples of $\mathrm{PM}_{2.5}$ for PBM determinations were taken at the RIEP station from a height of $4 \mathrm{~m}$ above the ground. 

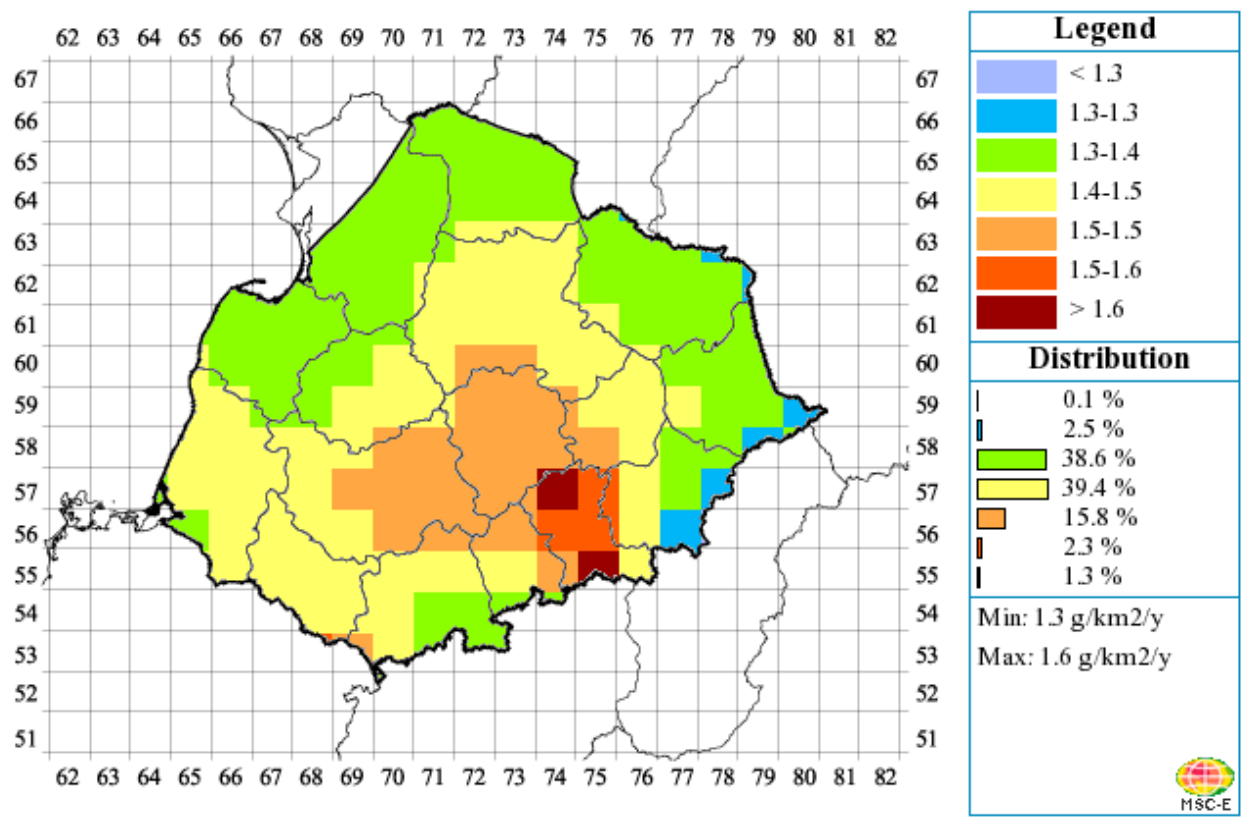

Figure 2. Annual mean concentrations of atmospheric $\mathrm{Hg}\left[\mathrm{ng} \mathrm{m}^{-3}\right]$ in Poland for 2015 over the EMEP domain (Meteorological Synthesizing Centre-East, 2017; Supplement to EMEP Status Reports 2/2017 and 3/2017 "Heavy metal and POP transboundary pollution in 2015: Concentration and deposition maps, source-receptor matrices, ecosystem-specific deposition and evaluation of model performance"; http://en.msceast.org/index.php/pollution-assessment/emep-domain-menu).

Złoty Potok is a village (1200 inhabitants) located in the north-eastern part of Silesian Province, about $20 \mathrm{~km}$ south-east of the city Częstochowa, and $45 \mathrm{~km}$ north-east of the Upper Silesian Agglomeration. The measurements of TGM and PBM concentrations were conducted at the air quality monitoring station $\left(\varphi=50^{\circ} 42^{\prime} 39^{\prime \prime} \mathrm{N}, \lambda=19^{\circ} 27^{\prime} 31^{\prime \prime} \mathrm{E}\right)$ belonging to the RIEP. The gaseous and particulate sampling heads were located at about $4 \mathrm{~m}$ above the ground level. The station is situated within a typical rural landscape, and, being located in a relatively weakly polluted area, it serves as regional background measuring station for Silesian Province.

\section{Measurement Methods}

\subsection{Measurements of Gas-Phase Mercury}

At the RIEP's station in Złoty Potok, TGM measurements were performed using Tekran 2537B (Tekran Inc., Toronto, ON, Canada), an automated analyzer of gaseous mercury. The measurement was based on the $\mathrm{Hg}$ amalgamation onto a gold cartridge (Au-trap), followed by thermal desorption in carrier gas and its detection as GEM via cold vapor atomic fluorescence spectrometry (CVAFS). The pre-filtered ambient air was passing through Au-trap to collect TGM. For continuous monitoring, the instrument utilized two Au-traps with alternating operation modes (collecting, desorbing, and chemical analysis) on a predefined time base ( $5 \mathrm{~min})$. It was calibrated daily using an internal mercury permeation source and checked periodically by manual injections of GEM from the Tekran 2505 calibration unit.

Another measurement scheme was used at the IEE's station in Zabrze for the Tekran 2537B/1130/1135 system. Coupled with various sample capture elements and selective desorption procedures, this system was used for quantitative analysis of speciated gaseous mercury, GEM, and GOM. The concentrations of TGM were determined indirectly as a sum of GEM and GOM. The air was pulled into the 1130 unit through an impactor designed to remove coarse particles. From the sample flowing over a $\mathrm{KCl}$-coated denuder, the GOM was trapped and then fine particles (here: $\mathrm{PM}_{2.5}$ ) were separated within the 1135 unit. The remaining GEM was carried to the main module of Tekran 2537B for 
analysis. The GOM was accumulated for $1 \mathrm{~h}$ while the GEM was pre-concentrated and detected every 5 min. After $1 \mathrm{~h}$ sampling, GOM was thermally desorbed as GEM, transferred into the 2537B module and quantified by CVAFS. Speciated Hg measurements made by Tekran 2537B/1130/1135 systems have been described in detail elsewhere [24,25]. The manufacturer precision of the Tekran $2537 \mathrm{~B}$ is $2 \%$ and the analytical detection limit of GEM is $<0.75 \mathrm{pg}$ for 5 -min sampling intervals (7.5 1 of ambient air) $[26,27]$.

In this study, the results of short-term TGM measurements were averaged over $24 \mathrm{~h}$ on a given day. Thanks to this aggregating procedure, it was possible to directly compare TGM and PBM concentrations and the risk quotients calculated for these concentrations.

\section{2. $\mathrm{PM}_{2.5}$ Sampling and Determination of Particulate Mercury}

At the both sites, 24-hour samples of $\mathrm{PM}_{2.5}$ were collected by means of low volume Mikro PNS samplers (Umwelttechnik MCZ GmbH, Bad Nauheim, Germany) with jet/impactor PM 2.5 sampling heads and automatic filter changers. The quartz fiber filters (Whatman QMA, minimum filtration capacity of $99.5 \%$ ) were used. The samples were taken at a height of about $4 \mathrm{~m}$ above the ground level (Figure 1), according to the European reference method for gravimetric determination of $\mathrm{PM}_{2.5} \mathrm{mass}$ concentration [28]. They were taken in series consisting of $1424 \mathrm{~h}$ samples each (the sampler magazines capacity), and each accompanied by a field blank sample. During the whole measurement period, the number of $n=652$ and $n=255$ samples were collected in Złoty Potok and Zabrze, respectively. Immediately after sampling, the filters from Złoty Potok were conditioned and weighed in the RIEP's laboratory in Czestochowa. Sections of these filters (and the weighing room and field blanks), each in a separate and sealed Petri dish, were transported using a thermo-container to the IEE's laboratory in Zabrze to determine the mercury contents. The samples collected in Zabrze were conditioned and weighed in the IEE's laboratory. To prevent $\mathrm{Hg}$ re-volatilization, all samples were stored in a freezer at $-18^{\circ} \mathrm{C}$ before the analyses. The procedures for conditioning, weighing, storage, and transport of the samples and of the blank sample preparation complied with the QA/QC procedures of the reference method for gravimetric measurements [28] and were described in detail in [29].

The Hg content was determined by applying cold-vapor atomic absorption spectrometry (CVAAS) to thermally decomposed $\mathrm{PM}_{2.5}$ samples. MA-2 analyzer (Nippon Instr. Co, Japan) was used. The section of exposed filter was placed in a boat and heated in the pipe furnace to $700{ }^{\circ} \mathrm{C}$ in a Hg-free air (carrier gas). The by-products of thermal decomposition (nitrogen oxides, sulfur dioxide, and halides) capable of interfering with $\mathrm{Hg}$ determination were eliminated by analytical additives and catalytic oxidation at $850^{\circ} \mathrm{C}$. Then, the decomposition products containing GEM, were passed through buffer solution ( $\mathrm{pH}=7$ ), and, after drying, for improving the determination selectivity, they were passed through gold trap with amalgam formation. GEM, released upon rapid heating of the gold trap, were carried to detector, where the light absorbance of the mixture $\mathrm{Hg} /$ carrier gas was measured at the wavelength $\lambda=253.7 \mathrm{~nm}$.

The analyzer was calibrated in the range of $0.1-6 \mathrm{ng}\left(\mathrm{R}^{2}=0.999\right)$. The calibration curve was obtained using calibration solutions. They were prepared based on the calibration standard (Inorganic Ventures, USA; certified Hg content: Hg $10 \mathrm{ppm}$ ). The method was validated using two standard reference materials: NIST1633b (Constituent Elements in Coal Fly Ash, certified Hg content: $0.1431 \pm 0.0018 \mathrm{mg} \mathrm{Hg} \mathrm{kg}^{-1}$ ) and NIST2583 (Trace Elements in Indoor Dust, certified Hg content: $\left.1.56 \pm 0.19 \mathrm{mg} \mathrm{Hg} \mathrm{kg}^{-1}\right)$. The mean standard recoveries $(\mathrm{n}=10$ ) were $90 \pm 4 \%$ (in the range from 85 to $99 \%$ ) for NIST $1633 \mathrm{~b}$ and $96 \pm 3 \%$ (from $73 \%$ to $102 \%$ ) for NIST 2583 . The limits of detection and quantification were determined by iteratively analyzing blank samples $(n=25)$ and they were 0.094 and $0.283 \mathrm{ng} \mathrm{Hg}$, respectively. The standard deviation was $4.5 \%$ for an actual sample and $3.9 \%$ for SRM1633b. The repeatability, computed as a relative standard deviation from $\mathrm{n}=25$ measurements, was $4.5 \%$ for the actual sample and $3.9 \%$ for the NIST1633b sample [30]. 


\section{Inhalation Exposure and Health Risk Assessment}

The estimation of the potential non-carcinogenic health risk through inhalation of gaseous and particulate Hg was based on the methodology developed by the USA. EPA in the Risk Assessment Guidance for Superfund (RAGS) Part F - Supplemental Guidance for Inhalation Risk Assessment [31]. RAGS Part F provides the toxicity values derived by the EPA Integrated Risk Information System (IRIS) as so called reference concentrations (RfCs) instead of the earlier intake-based approach, used by the inhalation component of RAGS Part A [32]. According to the previous RAGS approach, the inhalation exposure, expressed in terms of a chronic daily air intake (I) $\left[\mathrm{mg} \mathrm{kg}^{-1} \mathrm{day}^{-1}\right]$, was evaluated as a function of the contaminant concentration in the air (CA), inhalation rate (IR), body weight (BW), the exposure time (ET), exposure frequency (EF), and its duration (ED), as well as the averaging time (AT), in the following way:

$$
\mathrm{I}=\mathrm{CA} \times(\mathrm{IR} / \mathrm{BW}) \times(\mathrm{ET} \times \mathrm{EF} \times \mathrm{ED}) / \mathrm{AT},
$$

According to the Supplemental Guidance for Inhalation Risk Assessment of RAGS Part F [31], the inhalation exposure should be expressed as the exposure concentration EC $\left[\mathrm{mg} \mathrm{m}^{-3}\right]$ and calculated as follows:

$$
\mathrm{EC}=\mathrm{CA} \times(\mathrm{ET} \times \mathrm{EF} \times \mathrm{ED}) / \mathrm{AT},
$$

where:

- $\quad \mathrm{CA}\left[\mathrm{mg} \mathrm{m}^{-3}\right]=24 \mathrm{~h}$ concentrations of mercury species in the air (TGM or PBM);

- $\quad$ ET [hours day $\left.{ }^{-1}\right]=$ exposure time, here: 24 h day $^{-1}$;

- $\quad \mathrm{EF}\left[\right.$ days year $\left.{ }^{-1}\right]=$ exposure frequency, here: 365 days year $^{-1}$;

- $\quad \mathrm{ED}$ [years] = exposure duration, here: lifespan 70 years;

- $\mathrm{AT}$ [hours] = averaging time calculated as the product of ED, EF and ET, here: (70 years $\times$ 365 days year ${ }^{-1} \times 24 \mathrm{~h} \mathrm{day}^{-1}$ ).

In order to estimate EC, an appropriate exposure scenario must be adopted. Despite the fact that, in a moderate climate, people spend most of their lifetime indoors (where $\mathrm{Hg}$ concentrations may be higher than those outside in ambient air [33]), we assumed that the inhabitants of Zabrze and Złoty Potok were constantly exposed to the atmospheric Hg concentrations. We assumed the most conservative exposure time, frequency, and its duration, lasting $24 \mathrm{~h}$ over the whole human lifespan. The uncertainties associated with such a choice are obvious and undisputed; however, in this study, we tried to estimate not the most likely exposure scenario but the worst case one, where exposure concentration is equal to $\mathrm{Hg}$ concentration in the air $(\mathrm{EC}=\mathrm{CA})$. When assessing EC, we did not include any age-dependent exposure variability. Inclusion of subsequent exposure variables into the risk model often causes the predictions to become more hypothetical.

The hazard quotient (HQ, unitless) reflecting the potential non-carcinogenic effect for the inhalation pathway was calculated separately for each $\mathrm{Hg}$ form with the following general equation:

$$
\mathrm{HQ}=\mathrm{EC} / \mathrm{RfC},
$$

where $\mathrm{RfC}\left[\mathrm{mg} \mathrm{m}^{-3}\right]=$ reference concentration for chronic inhalation exposure.

In this study we used the inhalation $\mathrm{RfC}=3 \times 10^{-4} \mathrm{mg} \mathrm{m}^{-3}$ for elemental mercury, which is available in the IRIS database (https://cfpub.epa.gov/ncea/iris2/chemicalLanding.cfm?\&substance_nmbr=370). The RfC for mercury is based on the assumption that thresholds exist for certain neurobehavioral effects. This value was set by EPA on the basis of some studies on workplace exposure with a high uncertainty factor [34]. We used the same RfC value for the both $\mathrm{Hg}$ forms, TGM and PBM. There is no separate inhalation RfC for particulate mercury or aerosol form of inorganic compounds, e.g., mercuric chloride, in the IRIS database (such RfC is under development). 
For comparison purposes, we also used the proposal of revised reference concentration for elemental mercury $\left(\mathrm{RfC}_{\mathrm{R}}=0.7 \times 10^{-4} \mathrm{mg} \mathrm{m}^{-3}\right)$, presented by Lettmeier and co-authors [34] and based on the intensive cohort study.

The hazard index (HI, unitless) was applied to assess the cumulative risk of inhalation exposure to the both $\mathrm{Hg}$ forms. It was calculated as a sum of HQs:

$$
\mathrm{HI}=\mathrm{HQ}_{\mathrm{TGM}}+\mathrm{HQ}_{\mathrm{PBM}} \text {, }
$$

$\mathrm{HI}$ or HQ values not exceeding 1 indicate no risk to health, while values above 1 indicate the risk of non-carcinogenic effects [32].

\section{Results and Discussion}

\subsection{TGM and PBM Concentrations in the Air}

Time series of 24-h concentrations of TGM and PBM in Zabrze and Złoty Potok are shown in Figure 3.

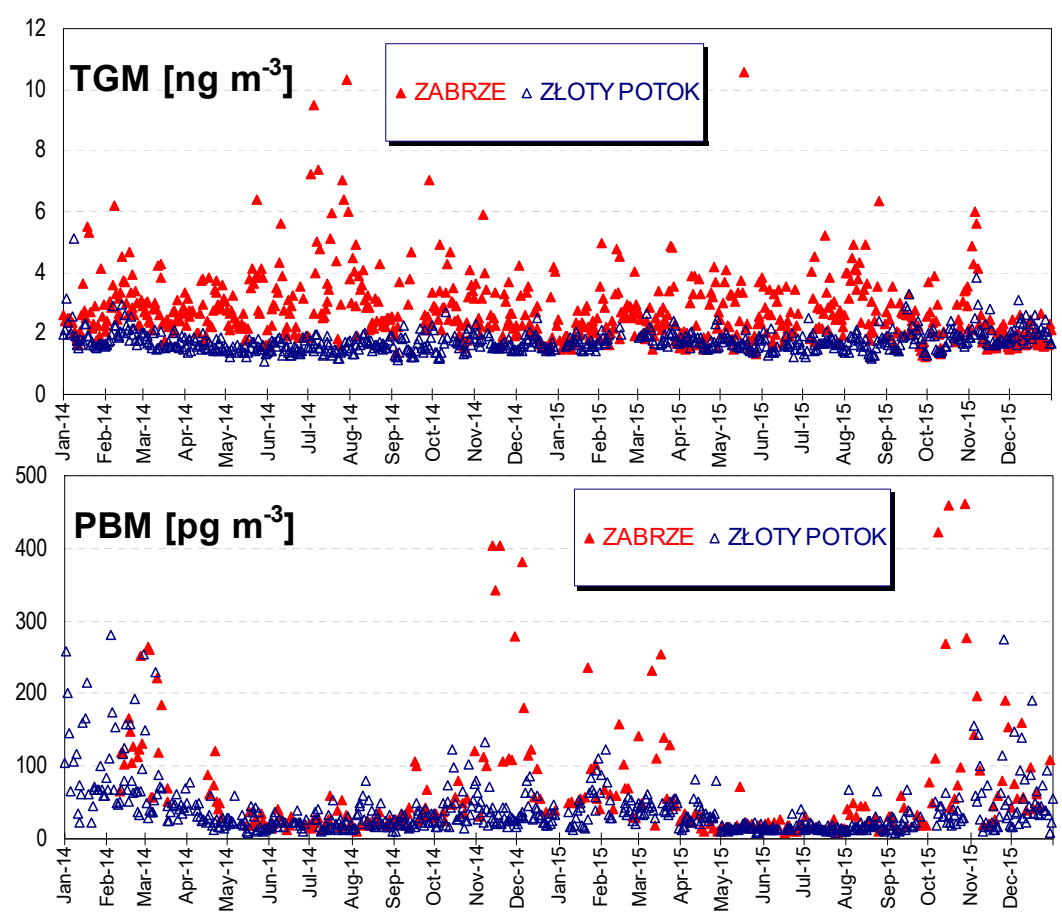

Figure 3. Daily concentrations of total gaseous mercury [TGM] and $\mathrm{PM}_{2.5}$-bound mercury [PBM] in Zabrze (urban background) and Złoty Potok (rural background), in the period of 2014-2015.

In order to demonstrate statistically significant differences between the distributions of $\mathrm{Hg}$ concentrations at both locations, first the normality of each distribution was checked, and then the appropriate test was selected to verify the above hypothesis. The normality was checked by using the non-parametric Shapiro-Wilk test (Statistica StatSoft ver.10). Daily averaged TGM concentrations and $24 \mathrm{~h}$ PBM data, both the raw and log-transformed ones, showed non-normal distributions $(p<0.001)$. The ratio of skewness to its standard error was $>2$ for gaseous and particulate $\mathrm{Hg}$ which indicates that the data are highly right-skewed. For such asymmetric distribution, where arithmetic mean is typically greater than median, the latter was selected as a measure of a central tendency. The descriptive statistics for $\mathrm{Hg}$ data are presented in Tables 1 and 2, with a distinction into summer season (a non-heating period from April to September) and winter (heating) season (the other 6 months). As a result of the U Mann-Whitney test, statistically significant differences between the distributions of $\mathrm{Hg}$ concentrations in Zabrze and Złoty Potok and their seasonality (summer vs. winter season) were confirmed $(p<0.05)$. 
Table 1. Descriptive statistics of the measurement results ( $24 \mathrm{~h}$ concentrations) of total gaseous mercury (TGM) and $\mathrm{PM}_{2.5}$-bound mercury (PBM) at the urban background station in Zabrze, 2014-2015.

\begin{tabular}{cccc}
\hline Statistical Parameter & Summer Season & Winter Season & Whole Period \\
\hline & TGM & & \\
\hline Min - Max $\left[\mathrm{ng} \mathrm{m}^{-3}\right]$ & $1.21-23.26$ & $1.34-6.21$ & $1.21-23.26$ \\
\hline Mean \pm SD $\left[\mathrm{ng} \mathrm{m}^{-3}\right]$ & $3.06 \pm 2.02$ & $2.57 \pm 0.87$ & $2.81 \pm 1.56$ \\
\hline Median $\left[\mathrm{ng} \mathrm{m}^{-3}\right]$ & 2.66 & 2.40 & 2.48 \\
\hline 95 percentile $\left[\mathrm{ng} \mathrm{m}^{-3}\right]$ & 5.17 & 4.26 & 4.76 \\
\hline Number of measurements & 331 & 351 & 682 \\
\hline & PBM & & \\
\hline Min - Max $\left[\mathrm{pg} \mathrm{m}^{-3}\right]$ & $7.64-121.06$ & $18.78-565.67$ & $7.64-565.67$ \\
\hline Mean \pm SD $\left[\mathrm{pg} \mathrm{m}^{-3}\right]$ & $27.68 \pm 18.62$ & $118.74 \pm 106.58$ & $69.81 \pm 86.53$ \\
\hline Median $\left[\mathrm{pg} \mathrm{m}^{-3}\right]$ & 21.58 & 80.21 & 37.87 \\
\hline 95 percentile $\left[\mathrm{pg} \mathrm{m}^{-3}\right]$ & 62.40 & 385.15 & 255.89 \\
\hline Number of measurements & 137 & 118 & 255 \\
\hline
\end{tabular}

Table 2. Descriptive statistics of the measurement results (24 h concentrations) of total gaseous mercury (TGM) and $\mathrm{PM}_{2.5}$-bound mercury (PBM) at the rural background station in Złoty Potok, 2014-2015.

\begin{tabular}{cccc}
\hline Statistical Parameter & Summer Season & Winter Season & Whole Period \\
\hline & TGM & & \\
\hline Min-Max $\left[\mathrm{ng} \mathrm{m}^{-3}\right.$ ] & $1.09-3.28$ & $1.19-5.11$ & $1.0-5.11$ \\
\hline Mean \pm SD $\left[\mathrm{ng} \mathrm{m}^{-3}\right.$ ] & $1.65 \pm 0.27$ & $1.85 \pm 0.39$ & $1.74 \pm 0.35$ \\
\hline Median $\left[\mathrm{ng} \mathrm{m}^{-3}\right.$ ] & 1.60 & 1.76 & 1.69 \\
\hline 95 percentile $\left[\mathrm{ng} \mathrm{m}^{-3}\right]$ & 2.10 & 2.51 & 2.31 \\
\hline Number of measurements & 358 & 326 & 684 \\
\hline & PBM & & $7.44-281.71$ \\
\hline Min-Max $\left[\mathrm{pg} \mathrm{m}^{-3}\right.$ ] & $7.44-82.49$ & $7.67-281.71$ & $38.48 \pm 36.01$ \\
\hline Mean \pm SD $\left[\mathrm{pg} \mathrm{m}^{-3}\right.$ ] & $22.84 \pm 12.76$ & $54.77 \pm 44.27$ & 27.82 \\
\hline Median $\left[\mathrm{pg} \mathrm{m}^{-3}\right.$ ] & 19.19 & 42.68 & 102.21 \\
\hline 95 percentile $\left[\mathrm{pg} \mathrm{m}^{-3}\right.$ ] & 49.40 & 150.57 & 647 \\
\hline Number of measurements & 330 & 317 &
\end{tabular}

As can be seen in Figure 3, the higher TGM and PBM concentrations with clearly higher dispersion of data were obtained at the urban site in Zabrze. For this site, the overall median concentration of TGM and PBM was about 14 times higher than in Złoty Potok, and the standard deviations of TGM and PBM data were 45 and 24 times higher, respectively. To the best of our knowledge the concentrations of TGM and PBM in Zabrze were higher than anywhere else in Europe, excluding historical mercury mining areas in Spain, Slovenia, or Italy [35]. However, it should be noted that city locations of $\mathrm{Hg}$ monitoring stations are rather rare in Europe. Most of these stations are located in the coastal strip (cleaning effect of the sea breeze) or inland, in rural or remote sites. The nearest station of atmospheric $\mathrm{Hg}$ monitoring in Central Europe is German Waldhof (100km south-east of Hamburg), but this is a rural background site, more representative for our second station in Złoty Potok than for Zabrze. Selected results of TGM and PBM measurements in European locations and for comparison, in some urban sites of North America and Asia, are summarized in Table 3. The mean of TGM concentrations in Zabrze was lower than for Chinese cities, similar to those found in Seoul (South Korea), 2012-2013, and higher than reported by Mao and co-authors [36] for urban sites in Europe, North America, and Asia (median $2.1 \mathrm{ng} \mathrm{m}^{-3}$ ). 
Table 3. Comparison of TGM and PBM concentrations in selected sites in Europe, North America, and Asia.

\begin{tabular}{|c|c|c|c|c|c|}
\hline Country, Site of Measurements & Site Description & Period & $\begin{array}{l}\text { TGM/GEM/ } \\
{\left[\mathrm{ng} \mathrm{m}^{-3}\right]^{*}}\end{array}$ & $\begin{array}{c}\mathrm{PBM} \\
{\left[\mathrm{pg} \mathrm{m}^{-3}\right]^{*}}\end{array}$ & Reference \\
\hline \multicolumn{6}{|c|}{ Europe } \\
\hline Germany, Waldhof & $\begin{array}{c}\text { rural } \\
\text { (Central- European } \\
\text { background) }\end{array}$ & 2009-2011 & $\begin{array}{c}\text { /GEM/ } \\
1.61 \\
1.1-3.1\end{array}$ & $\begin{array}{c}6.30 \\
0.4-110\end{array}$ & [37] \\
\hline $\begin{array}{l}\text { UK (Scotland), Auchencorth } \\
\text { Moss }\end{array}$ & rural & 2009-2011 & $\begin{array}{c}\text { /GEM/ } \\
1.40 \pm 0.19\end{array}$ & $3.11 \pm 5.34$ & [38] \\
\hline $\begin{array}{l}\text { UK (England: London, } \\
\text { Manchester Sheffield; Ireland: } \\
\text { Belfast; Scotland: Motherwell; } \\
\text { Wales: Cardiff, Swansea) }\end{array}$ & urban & 2004-2013 & $\begin{array}{c}2.07 \pm 0.03 \\
\text { (manual measurement) }\end{array}$ & - & [39] \\
\hline \multirow[b]{2}{*}{$\begin{array}{l}\text { Ireland, Mace Head } \\
\text { (North Atlantic) }\end{array}$} & \multirow{2}{*}{$\begin{array}{l}\text { regional } \\
\text { background, } \\
\text { coastal site }\end{array}$} & 1996-2009 & $1.65 \pm 0.13$ & - & [40] \\
\hline & & 2012-2015 & $\begin{array}{c}1.48 \\
1.48 \pm 0.13\end{array}$ & - & [41] \\
\hline $\begin{array}{l}\text { Sweden, Råö } \\
\text { (Baltic Sea) }\end{array}$ & rural, coastal site & 2012-2015 & $\begin{array}{c}\text { /GEM/ } \\
1.41 \\
1.42 \pm 0.20\end{array}$ & $\begin{array}{c}2.21 \\
3.6 \pm 4.5\end{array}$ & [41] \\
\hline $\begin{array}{l}\text { Germany, Zingst } \\
\text { (Baltic Sea) }\end{array}$ & rural, coastal site & 1998-2004 & 1.66 & - & [42] \\
\hline $\begin{array}{l}\text { Sweden, Göteborg } \\
\text { (Baltic Sea) }\end{array}$ & urban, coastal site & 2005 & $1.96 \pm 0.38$ & $2.53 \pm 4.09$ & [43] \\
\hline $\begin{array}{l}\text { Portugal, Porto } \\
\text { (Atlantic Ocean) }\end{array}$ & $\begin{array}{l}\text { suburban } \\
\text { coastal site }\end{array}$ & 2008-2014 & $\begin{array}{l}1.93 \text { (mean) } \\
0.51-67.9\end{array}$ & - & [44] \\
\hline $\begin{array}{l}\text { Poland, Zabrze } \\
\quad \text { (Silesia) }\end{array}$ & urban & 2014-2015 & $\begin{array}{c}2.48 \\
2.81 \pm 1.56\end{array}$ & $\begin{array}{c}37.87 \\
69.81 \pm 86.53\end{array}$ & this study \\
\hline $\begin{array}{l}\text { Poland, Złoty Potok } \\
\text { (Silesia) }\end{array}$ & $\begin{array}{l}\text { rural, regional } \\
\text { background }\end{array}$ & 2014-2015 & $\begin{array}{c}1.69 \\
1.74 \pm 0.35\end{array}$ & $\begin{array}{c}27.82 \\
38.48 \pm 36.01\end{array}$ & this study \\
\hline \multicolumn{6}{|c|}{ North America } \\
\hline \multirow[t]{2}{*}{ USA, Reno NV } & \multirow[t]{2}{*}{ urban } & $2002-2005$ & $\begin{array}{c}2.3 \text { (mean) } \\
2.1 \text { (median) } \\
0.9-8.6\end{array}$ & & [45] \\
\hline & & $2007-2009$ & $2.0 \pm 0.7$ & $7.0 \pm 7.0$ & [46] \\
\hline $\begin{array}{c}\text { USA, Birmingham AL, New } \\
\text { York City, Rochester NY, Salt } \\
\text { Lake City UT }\end{array}$ & $\begin{array}{c}\text { urban } \\
(A M N e t)\end{array}$ & 2009-2011 & $\begin{array}{c}\text { /GEM/ } \\
1.51 \\
1.65 \pm 1.36 \\
0.4-237.7\end{array}$ & $\begin{array}{c}4.97 \\
8.46 \pm 29.05 \\
0-3687\end{array}$ & [47] \\
\hline $\begin{array}{l}\text { Canada, Halifax } \\
\text { (North Atlantic) }\end{array}$ & $\begin{array}{c}\text { urban, } \\
\text { costal site }\end{array}$ & 2010-2011 & $\begin{array}{l}\text { /GEM/ } \\
1.7 \pm 1.0\end{array}$ & $2.3 \pm 3.1$ & [48] \\
\hline \multicolumn{6}{|c|}{ Asia } \\
\hline China (Southeast Ch.), Xiamen & urban & $2012-2013$ & $\begin{array}{c}\text { /GEM/ } \\
3.50 \pm 1.21\end{array}$ & $174.4 \pm 280.6$ & [49] \\
\hline China (Eastern Ch.), Jinan & urban & $2015-2016$ & $4.91 \pm 3.66$ & $451.9 \pm 433.4$ & [50] \\
\hline China, Beijing & urban & 2016-2017 & $\begin{array}{c}\text { /GEM/ } \\
4.70 \pm 3.53\end{array}$ & $85.18 \pm 95.34$ & [51] \\
\hline $\begin{array}{l}\text { China (Northwest Ch.), } \\
\text { Lanzhou }\end{array}$ & urban & 2016-2017 & $4.48 \pm 2.32$ & - & [52] \\
\hline South Korea, Seoul & urban & 2006-2009 & $\begin{array}{l}3.72 \pm 2.96 \\
0.19-149.84\end{array}$ & $\begin{array}{c}13.4 \pm 12.0 \\
2.1-64.3\end{array}$ & [53] \\
\hline South Korea, Seoul & urban & 2012-2013 & $2.34 \pm 0.73$ & - & [54] \\
\hline \multicolumn{3}{|c|}{ Northern Hemisphere background } & $1.5-1.7$ & - & [5] \\
\hline
\end{tabular}

* TGM/GEM/and PBM concentrations - as: Median; Mean \pm SD or Minimum-Maximum; AMNet - Atmospheric mercury network. 
At the Zabrze location, higher TGM concentrations were recorded in summer than in winter season, in contrast to the seasonal variation of anthropogenic mercury emissions. This is an overlapping effect of meteorological and emission conditions, as well as the air inlet elevation (14 $\mathrm{m}$ a.g.1.). The elevated inlet allowed for recording the peak $\mathrm{Hg}$ concentrations in the summer season, caused by the local sources, including high emitters. In winter, the impact of higher emitters was limited due to the thermal inversion phenomenon, which prevents the pollution plumes from reaching the ground level. A similar seasonal ratio of TGM concentrations, resulting from the specified diurnal pattern in warmer months (with maximum at night, Figure 4), has been reported in other urban and industrial areas [36,55].
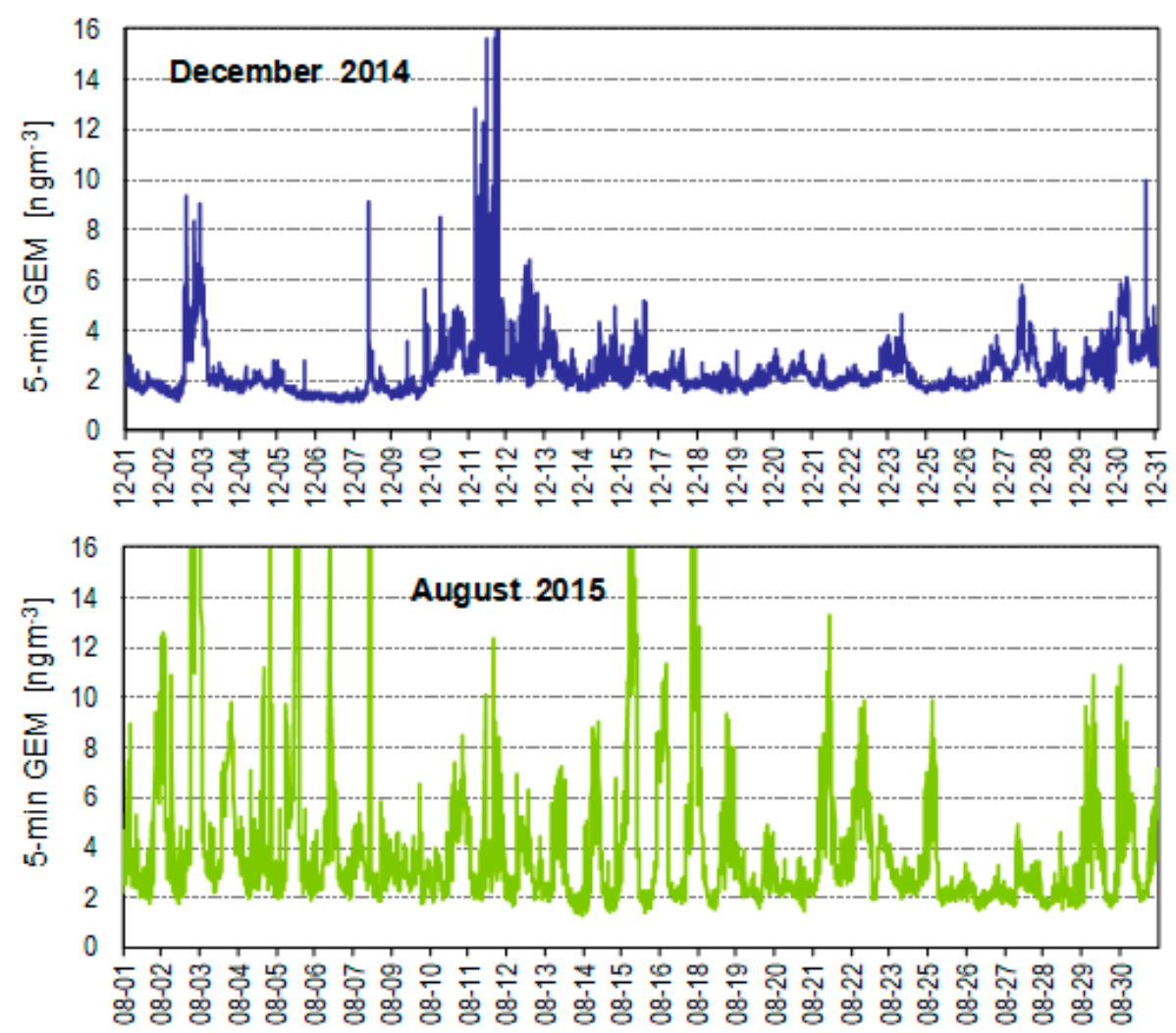

Figure 4. The concentrations of 5min GEM in December 2014 and August 2015 at the urban site in Zabrze (no diurnal pattern in winter and clear periodicity in summer with nocturnal maximum).

At the rural background station in Złoty Potok, a higher mean TGM concentration (by 12\%) was obtained in the winter season, which is in line with the literature. According to [36], the predominant seasonal TGM/GEM trend at rural sites is the winter-to-early-spring maximum and summer minimum. Higher TGM concentrations in Złoty Potok in winter season were mainly driven by the anthropogenic mercury emissions for heating purposes (coal combustion throughout the region and local biomass burning) and limited mixing in the ground boundary layer, and to a lesser extent by poor GEM oxidation and less scavenging.

For both locations, Złoty Potok and Zabrze, very high PBM concentrations were obtained, well above the Central-European background (Waldhof, Germany) or levels at urban sites of Europe and North America, and closer to the values recorded in Chinese cities (Table 3). For comparison, Mao and co-authors [36] reported that the median PBM concentration was $10.0 \mathrm{pgm}^{-3}$ at urban sites and $4.6 \mathrm{pgm}^{-3}$ at rural sites, located on land, in non-polar regions of the Northern Hemisphere. Such high PBM concentrations are the result of the widespread use of coal burning in Silesia (and all over Poland) for heat and power generation $[29,56]$. The concentrations of PBM were proportional to high $\mathrm{PM}_{2.5}$ concentrations, which was $23 \mu^{-3} \mathrm{~m}^{-3}$ (median) in Zabrze and $16 \mu^{-3} \mathrm{~m}^{-3}$ in Złoty Potok during the whole analyzed period. The median $\mathrm{PM}_{2.5}$ concentration in Zabrze was three times higher in heating 
season than in summer. For Złoty Potok, this ratio amounted to 1.8. This was the main (and primary) reason for the statistically significant differences in PBM levels between the winter and summer seasons. Moreover, in the colder season the mercury contents in the $\mathrm{PM}_{2.5}$ samples were clearly higher than in summer. For Złoty Potok they amounted to 1.9 and $1.5 \mathrm{ng} \mathrm{mg}^{-1}$, respectively, and to 1.5 and $1.2 \mathrm{ng}$ $\mathrm{m}^{-1}$ for Zabrze. Winter enrichment of $\mathrm{PM}_{2.5}$ samples with mercury by an additional $25 \%$, compared to the summer season, was essentialy a secondary effect of lower temperature, higher relative humidity, and lower $\mathrm{Hg}$ vapor pressure. These factors led to a shift in the gas-particle partitioning towards the sorption of GOM on the solid particles.

\subsection{Health Risk Resulting from Inhalation of TGM and PBM}

The seasonal distributions of daily HQs, calculated for the current EPA's RfC $=0.3 \mu \mathrm{gm}^{-3}$, separately for TGM and PBM at the urban and rural station, are shown on the box plots in Figure 5 . Each box includes the median (midline) and 25th and 75th percentiles (box edges). "Max" denotes the maximum value of HQs, which is representative rather for acute exposure and short-term (daily) risk. The measure of chronic exposure and the corresponding potential health risk is the median (or mean) of HQs. In our opinion the median values of HQs are more representative for right-skewed concentrations data; however, they are lower than the mean ones. Therefore, in Table 4 we compiled both the median and mean of HQs and HIs.
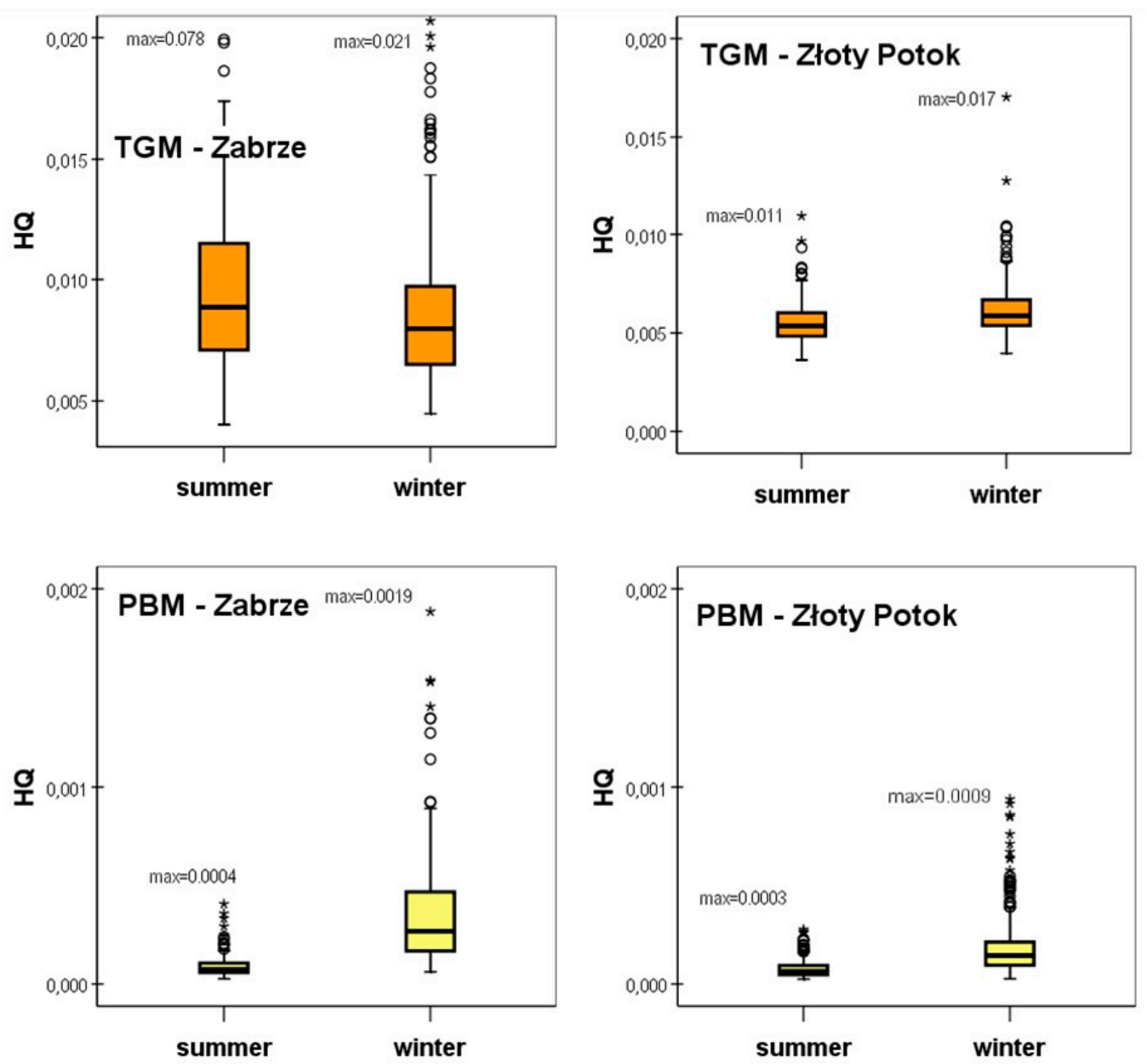

Figure 5. Seasonal distributions of hazard quotients (HQ) for total gaseous mercury (TGM) and $\mathrm{PM}_{2.5}$-bound mercury (PBM) in Zabrze (urban background) and Złoty Potok (rural background), in the period of 2014-2015. 
Table 4. The median and mean of hazard quotients (HQ) and hazard indexes (HI) for TGM and PBM concentrations in Zabrze and Złoty Potok (2014-2015) and the actual EPA's reference concentration $\mathrm{RfC}=0.3 \mu \mathrm{gm}^{-3}$.

\begin{tabular}{ccccccc}
\hline \multirow{2}{*}{ Statistical Parameter } & \multicolumn{2}{c}{ HQ for TGM } & \multicolumn{2}{c}{ HQ for PBM } & \multicolumn{2}{c}{ HI for TGM and PBM } \\
\cline { 2 - 7 } & Zabrze & Złoty Potok & Zabrze & Złoty Potok & Zabrze & Złoty Potok \\
\hline \multicolumn{7}{c}{ Summer season } \\
\hline Median [unitless] & 0.00886 & 0.00535 & 0.00007 & 0.00006 & 0.00893 & 0.00541 \\
\hline Mean [unitless] & 0.01020 & 0.00548 & 0.00009 & 0.00008 & 0.01029 & 0.00556 \\
\hline \multicolumn{7}{c}{ Winter season } \\
\hline Median [unitless] & 0.00798 & 0.00587 & 0.00027 & 0.00014 & 0.00825 & 0.00601 \\
\hline Mean [unitless] & 0.00856 & 0.00616 & 0.00040 & 0.00018 & 0.00896 & 0.00634 \\
\hline \multicolumn{7}{c}{ Whole period } \\
\hline Median [unitless] & 0.00828 & 0.00562 & 0.00013 & 0.00009 & 0.00840 & 0.00571 \\
\hline Mean [unitless] & 0.00936 & 0.00581 & 0.00023 & 0.00013 & 0.00959 & 0.00593 \\
\hline
\end{tabular}

The median of the hazard quotient values in case of TGM concentrations in a more polluted urban area was 0.00828 throughout the entire analyzed period, therefore well below the $\mathrm{HQ}=1$ considered to pose a health risk.

Proportionally to the seasonal variations in TGM concentrations in Zabrze, the HQ value was 11\% higher in summer season compared to winter one (median HQ was 0.00886 and 0.00798 , respectively). The median of TGM HQs for the whole period in Złoty Potok amounted to approximately $68 \%$ of the corresponding HQs value in Zabrze. For the mean values, this proportion was only slightly lower and equal $62 \%$.

Regarding the median of PBM concentrations, the percentage share of $\mathrm{HQ}$ in $\mathrm{HI}$ in the whole analyzed period was $1.5 \%$ in Zabrze, and $1.6 \%$ in the case of Złoty Potok. For the mean values, these percentages were slightly higher ( 2.4 and $2.2 \%$, respectively). The shares of HQ in HI for PBM increased on average by $1-2 \%$ in the winter season. They did not exceed $5 \%$ at both locations and did not significantly affect the level of the $\mathrm{HI}$ index.

Moreover, we calculated the HQs for TGM, PBM and the HIs resulting from the exposure to those species taking into account the revised reference concentration $\mathrm{RfC}_{\mathrm{R}}=0.07 \mu \mathrm{gm}^{-3}$ [34], which is over four times lower than the current EPA's RfC value (Table 5). In addition, in this case, the HI for the whole analyzed period was around 0.04 in Zabrze and did not exceed 0.03 in Złoty Potok, i.e., significantly below the value recommended by U.S. EPA as posing a health risk $(\mathrm{HI}=1)$.

Table 5. The median and mean of hazard quotients (HQ) and hazard indexes (HI) for TGM and PBM concentrations in Zabrze and Złoty Potok (2014-2015) and the proposal of revised EPA's reference concentration $\operatorname{RfC}_{\mathrm{R}}=0.07 \mu \mathrm{gm}^{-3}$.

\begin{tabular}{ccccccc}
\hline \multirow{2}{*}{ Statistical Parameter } & \multicolumn{2}{c}{ HQ for TGM } & \multicolumn{2}{c}{ HQ for PBM } & \multicolumn{2}{c}{ HI for TGM and PBM } \\
\cline { 2 - 7 } & Zabrze & Zloty Potok & Zabrze & Złoty Potok & Zabrze & Złoty Potok \\
\hline \multicolumn{7}{c}{ Summer season } \\
\hline Median [unitless] & 0.03798 & 0.02293 & 0.00031 & 0.00027 & 0.03829 & 0.02320 \\
\hline Mean [unitless] & 0.04371 & 0.02350 & 0.00040 & 0.00033 & 0.04411 & 0.02383 \\
\hline \multicolumn{7}{c}{ Winter season } \\
\hline Median [unitless] & 0.03422 & 0.02516 & 0.00115 & 0.00061 & 0.03536 & 0.02577 \\
\hline Mean [unitless] & 0.03669 & 0.02640 & 0.00170 & 0.00078 & 0.03838 & 0.02718 \\
\hline \multicolumn{7}{c}{ Whole period } \\
\hline Median [unitless] & 0.03548 & 0.02409 & 0.00054 & 0.00040 & 0.03602 & 0.02449 \\
\hline Mean [unitless] & 0.04010 & 0.02488 & 0.00100 & 0.00055 & 0.04109 & 0.02543 \\
\hline
\end{tabular}


It is difficult to compare the obtained results of the assessment of hazard indexes with data from other places in the world, as we have not found similar exposure scenarios for calculating the cumulative inhalation risk resulting from TGM and PBM. Available literature evidences refer to either partial exposure to extremely high concentrations of gaseous mercury resulting from artisanal or small-scale gold production [57,58], partial exposure to aerosol mercury present in particles suspended in the air [59,60], or in settled dust [61,62]. Taking into account even one mercury intoxication pathway (e.g., by inhalation) and one form of mercury (e.g., PM-bound) the comparison of the HQ values in different places around the world is possible only when using similar exposure scenario. The differences in HQs levels, when using different exposure scenarios, can reach 3-4 orders of magnitude and are not proportional to $\mathrm{Hg}$ concentrations in the air. Large variations in health risks levels resulting from $\mathrm{Hg}$ exposure often meet in the literature mostly result from the lack of standardization regarding formulas used for calculating chronic daily air intake (I), formerly recommended by the U.S. EPA, among others, in relation to exposure estimation for soil compounds.

\section{Conclusions}

The paper presents results from a 2-year campaign of parallel measurements of gaseous mercury (TGM) and respiratory-related particulate mercury ( $\mathrm{PM}_{2.5}$-bound $\left.\mathrm{Hg}, \mathrm{PBM}\right)$ collected in one of the European hot spot areas regarding mercury and PM emission levels. Measurements were carried out in Silesia, the most industrialized and densely populated region of Southern Poland in two locations differing in terms of emission characteristics. The obtained results and the nature of the concentration distribution for both forms of mercury were compared in locations representative for conditions of urban-industrial agglomeration and non-urban (rural) background. The recorded levels of TGM and PBM concentrations were higher than those from the Waldhof station (Germany), which can be considered as reference for the typical background levels characteristic for Central Europe. In the case of the urban-background station, the median and average values of TGM and PBM concentrations were higher than those observed in European or American locations of similar nature, and closer to the levels recorded in some urban stations in Asia (e.g., in Seoul, South Korea). These data indicate a significant impact of emissions of anthropogenic origin, generally associated with the widespread combustion of hard coal for the purposes of energy and heat production in power generation companies and municipal energy sector, but also in industry and individual home furnaces. EC exposure concentrations were determined by assuming the most unfavorable scenario of exposure of adult residents of Silesia to inhalation of the above-mentioned atmospheric mercury species ( $24 \mathrm{~h}$ exposure throughout the life span), followed by HQ hazard quotients and cumulative hazard index (HI) calculations. U.S. EPA methodology was used in the calculations. For the estimation of chronic exposure to mercury through inhalation, an appropriate reference concentration (RfC) is currently recommended by EPA. Calculations of HQs and HIs in both locations, representing different exposure potencies to airborne mercury in Silesia, were repeated for the revised reference concentration $\mathrm{RfC}_{R}$, proposed by Lettmeier and co-authors [34]. The obtained HIs, even after recalculation with the revised $\mathrm{RfC}_{\mathrm{R}}$ value (4 times lower compared to $\mathrm{RfC}$ ), were about 0.04 at the urban background site in Zabrze and below 0.03 at rural background site in Złoty Potok, throughout the entire measurement period. Therefore, the critical value of $\mathrm{HI}=1$ was not exceed in any case, including the sub-periods: summer/heating season. This means that relatively high concentrations of TGM and PBM, similar to those meet in Silesia, do not pose an inhalation health threat for residents. Estimating the values of the HI exposure indexes, it was found that, for PBM, the HQs constitute approximately $1 \%$ to $5 \%$ of the total HIs values. Thus, despite high PBM concentrations found in this study, compared to other places in Europe or North America, the proportion of PM-bound mercury is rather marginal in creating the cumulative $\mathrm{Hg}$-dependent inhalation risk. Looking for literature confirmation of the correctness of the HQs and HIs calculations made in our work, it was noticed that even taking into account only single intoxication pathway and one form of mercury, it is strictly impossible to compare HQs calculated for different places in the world. The differences in HQs levels reach 3-4 orders of 
magnitude and do not reflect the actual levels of $\mathrm{Hg}$ occurrence in the environment. They result from the use of various calculation formulas, including those recommended by U.S. EPA. For the need of comparability, there exists a need for harmonization of the HQ estimation approach able to include variation resulting from multiple sources (multi-environment) of $\mathrm{Hg}$ origin and multiple absorption paths (multi-path).

Author Contributions: Conceptualization, H.P. and K.W.-R.; Data curation, K.S.; Formal analysis, H.P.; Funding acquisition, H.P.; Investigation, H.P. and K.S.; Methodology, H.P. and K.W.-R.; Project administration, H.P.; Supervision, H.P.; Validation, H.P.; Writing - original draft, H.P. and K.W.-R.; Writing - review \& editing, H.P. and K.W.-R. All authors have read and agreed to the published version of the manuscript.

Funding: The chemical analysis of $\mathrm{PM}_{2.5}$ samples was financed from the Regional Environmental Protection Fund in Katowice special purpose subsidy, as a part of cooperation with Regional Inspectorate for Environmental Protection in Katowice in the field of regional monitoring of atmospheric mercury during 2014-2015.

Acknowledgments: Automatic monitoring of mercury in Zabrze was possible thanks to the financial support under the statutory work performed at the Institute of Environmental Engineering Polish Academy of Sciences in the Air Protection Department.

Conflicts of Interest: The authors declare no conflict of interest. The funder had no role in the design of the study; in the collection, analyses, or interpretation of data; in the writing of the manuscript, or in the decision to publish the results.

\section{References}

1. Selin, N.E. Global biogeochemical cycling of mercury: A review. Annu. Rev. Environ. Resour. 2009, 34, 43-63. [CrossRef]

2. Song, S.; Selin, N.E.; Soerensen, A.L.; Angot, H.; Artz, R.; Brooks, S.; Brunke, E.-G.; Conley, G.; Dommergue, A.; Ebinghaus, R.; et al. Top-down constraints on atmospheric mercury emissions and implications for global biogeochemical cycling. Atmos. Chem. Phys. 2015, 15, 7103-7125. [CrossRef]

3. Driscoll, C.T.; Mason, R.P.; Chan, H.M.; Jacob, D.J.; Pirrone, N. Mercury as a global pollutant: Sources, pathways and effects. Environ. Sci. Technol. 2013, 47, 4967-4983. [CrossRef]

4. Schroeder, W.H.; Munthe, J. Atmospheric mercury-An overview. Atmos. Environ. 1998, 32, 809-822. [CrossRef]

5. Lindberg, S.; Bullock, R.; Ebinghaus, R.; Engstrom, D.; Feng, X.; Fitzgerald, W.; Pirrone, N.; Prestbo, E.; Seigneur, $\mathrm{C}$. A synthesis of progress and uncertainties in attributing the sources of mercury in deposition. Ambio 2007, 36, 19-32. [CrossRef]

6. Pirrone, N.; Cinnirella, S.; Feng, X.; Finkelman, R.B.; Friedli, H.R.; Leaner, J.; Mason, R.; Mukherjee, A.B.; Stracher, G.B.; Streets, D.G.; et al. Global mercury emissions to the atmosphere from anthropogenic and natural sources. Atmospheric Chem. Phys. 2010, 10, 5951-5964. [CrossRef]

7. World Health Organization. Elemental Mercury and Inorganic Mercury Compounds: Human Health Aspects. Concise International Chemical Assessment Document 50. Geneva, Switzerland, 2003. Available online: https://www.who.int/ipcs/publications/cicad/en/cicad50.pdf?ua=1 (accessed on 9 July 2020).

8. Sundseth, K.; Pacyna, J.M.; Pacyna, E.G.; Pirrone, N.; Thorne, R.J. Global sources and pathways of mercury in the context of human health. Int. J. Environ. Res. Public Health 2017, 14, 105. [CrossRef] [PubMed]

9. Pacyna, J.M.; Travnikov, O.; De Simone, F.; Hedgecock, I.M.; Sundseth, K.; Pacyna, E.G.; Steenhuisen, F.; Pirrone, N.; Munthe, J.; Kindbom, K. Current and future levels of mercury atmospheric pollution on a global scale. Atmospheric Chem. Phys. 2016, 16, 12495-12511. [CrossRef]

10. United Nations Environment Programme. Global Mercury Assessment 2013: Sources, Emissions, Releases and Environmental Transport; UNEP Chemicals Branch: Geneva, Switzerland, 2013.

11. Boerleider, R.Z.; Roeleveld, N.; Scheepers, P.T.J. Human biological monitoring of mercury for exposure assessment. AIMS Environ. Sci. 2017, 4, 251-276. [CrossRef]

12. World Health Organization. Mercury and Health. 2017. Available online: https://www.who.int/news-room/ fact-sheets/detail/mercury-and-health (accessed on 9 July 2020).

13. Andreoli, V.; Sprovieri, F. Genetic aspects of susceptibility to mercury toxicity: An overview. Int. J. Environ. Res. Public Health 2017, 14, 93. [CrossRef] [PubMed] 
14. Sandborgh-Englund, G.; Elinder, C.G.; Johanson, G.; Lind, B.; Skare, I.; Ekstrand, J. The absorption, blood levels, and excretion of mercury after a single dose of mercury vapor in humans. Toxicol. Appl. Pharmacol. 1998, 150, 146-153. [CrossRef] [PubMed]

15. Agency for Toxic Substances and Disease Registry. Toxicological profile for Mercury 1999. U.S. Department of Health and Human Services, Centers for Disease Control and Prevention. Available online: http: //www.atsdr.cdc.gov/toxprofiles/tp46.html (accessed on 9 July 2020).

16. United Nations Environment Programme and World Health Organization. Guidelines for Identifying Populations at Risk from Mercury Exposure. UNEP Chemicals Branch and WHO, Department of Food Safety, Zoonoses and Foodborne Diseases: Geneva, Switzerland, 2008. Available online: http://www.who. int/foodsafety/publications/risk-mercury-exposure/en/ (accessed on 9 July 2020).

17. Clarkson, T.W.; Magos, L. The toxicology of mercury and its chemical compounds. Crit. Rev. Toxicol. 2006, 36, 609-662. [CrossRef] [PubMed]

18. Friberg, L.; Nordberg, F. Mercury, mercurials and mercaptans. In Inorganic Mercury-A Toxicological and Epidemiological Appraisal; Miller, M.W., Clarkson, T.W., Eds.; Charles C. Thomas: Springfield, IL, USA, 1973.

19. Clarkson, T.W. Mercury. J. Am. Coll. Toxicol. 1989, 8, 1291-1296. [CrossRef]

20. Boffetta, P.; Sällsten, G.; Garcia-Gómez, M.; Pompe-Kirn, V.; Zaridze, D.; Bulbulyan, M.; Caballero, J.D.; Ceccarelli, F.; Kobal, A.B.; Merler, E. Mortality from cardiovascular diseases and exposure to inorganic mercury. Occup. Environ. Med. 2001, 58, 461-466. [CrossRef]

21. International Agency for Research on Cancer. Mercury and mercury compounds. In Some Metals and Metal Compounds, and Occupational Exposures in the Glass Industry; IARC: Lyon, France, 1993; Volume 58.

22. European Environment Agency. European Union Emission Inventory Report 1990-2017 Under the UNECE Convention on Long-range Transboundary Air Pollution (LRTAP). EEA Report No 8/2019. Copenhagen. Available online: https://www.eea.europa.eu//publications/european-union-emissions-inventory-report2017 (accessed on 9 July 2020).

23. National Centre for Emissions Management (KOBiZE). Poland's Informative Inventory Report 2017. Submission under the UN ECE Convention on Long-Range Transboundary Air Pollution and the Directive (EU) 2016/2284; KOBiZE: Warsaw, Poland, 2017.

24. Landis, M.; Stevens, R.K.; Schaedlich, F.; Prestbo, E.M. Development and characterization of an annular denuder methodology for the measurement of divalent inorganic reactive gaseous mercury in ambient air. Environ. Sci. Technol. 2002, 36, 3000-3009. [CrossRef]

25. Gustin, M.S.; Amos, H.M.; Huang, J.; Miller, M.B.; Heidecorn, K. Measuring and modeling mercury in the atmosphere: A critical review. Atmos. Chem. Phys. 2015, 15, 5697-5713. [CrossRef]

26. Tekran. Model 2537B Ambient Mercury Vapor Analyzer User Manual, Ver. 3.11; Tekran Instruments Corporation: Toronto, ON, Canada, 2008.

27. Cole, A.S.; Steffen, A.; Eckley, C.S.; Narayan, J.; Pilote, M.; Tordon, R.; Graydon, J.A.; St. Louis, V.L.; Xu, X.; Branfireun, B.A. A survey of mercury in air and precipitation across Canada: Patterns and trends. Atmosphere 2014, 5, 635-668. [CrossRef]

28. The Polish Committee for Standardization. Ambient air. Standard Gravimetric Measurement Method for the Determination of the $P M_{10}$ or $P M_{2,5}$ Mass Concentration of Suspended Particulate Matter; The Polish Committee for Standardization: Warsaw, Poland, 2014.

29. Pyta, H.; Rogula-Kozłowska, W.; Mathews, B. Co-occurrence of $\mathrm{PM}_{2.5}$-bound mercury and carbon in rural areas affected by coal combustion. Atmos. Pollut. Res. 2017, 8, 127-135. [CrossRef]

30. Pyta, H.; Rogula-Kozłowska, W. Determination of mercury in size-segregated ambient particulate matter using CVAAS. Microchem. J. 2016, 124, 76-81. [CrossRef]

31. U.S. Environmental Protection Agency. Risk Assessment Guidance for Superfund Volume I: Human Health Evaluation Manual (Part. F, Supplemental Guidance for Inhalation Risk Assessment). Office of Superfund Remediation and Technology Innovation, US EPA: Washington, DC, USA, 2009. Available online: https: //www.epa.gov/sites/production/files/2015-09/documents/partf_200901_final.pdf (accessed on 9 July 2020).

32. U.S. Environmental Protection Agency. Risk Assessment Guidance for Superfund Volume I: Human Health Evaluation Manual (Part. A). Office of Emergency and Remedial Response, U.S. EPA: Washington, DC, 1989. Available online: https:/www.epa.gov/sites/production/files/2015-09/documents/rags_a.pdf (accessed on 9 July 2020). 
33. Majewski, G.; Widziewicz, K.; Rogula-Kozłowska, W.; Rogula-Kopiec, P.; Kociszewska, K.; Rozbicki, T.; Majder-Łopatka, M.; Niemczyk, M. PM origin or exposure duration? Health hazards from PM-bound mercury and PM-bound PAHs among students and lecturers. Int. J. Environ. Res. Public Health 2018, 15, 316. [CrossRef]

34. Lettmeier, B.; Boese-O'Reilly, S.; Drasch, G. Proposal for a Revised Reference Concentration (RfC) for mercury vapour in adults. Sci. Total Environ. 2010, 408, 3530-3535. [CrossRef]

35. Higueras, P.; Oyarzun, R.; Kotnik, J.; Esbrí, J.M.; Martínez-Coronado, A.; Horvat, M.; López-Berdonces, M.A.; Llanos, W.; Vaselli, O.; Nisi, B.; et al. A compilation of field surveys on gaseous elemental mercury (GEM) from contrasting environmental settings in Europe, South America, South Africa, and China: Separating fads from facts. Environ. Geochem. Health 2014, 36, 713-734. [CrossRef] [PubMed]

36. Mao, H.; Cheng, I.; Zhang, L. Current understanding of the driving mechanisms for spatiotemporal variations of atmospheric speciated mercury: A review. Atmos. Chem. Phys. 2016, 16, 12897-12924. [CrossRef]

37. Weigelt, A.; Temme, C.; Bieber, E.; Schwerin, A.; Schuetze, M.; Ebinghaus, R.; Kock, H.-H. Measurements of atmospheric mercury species at a German rural background site from 2009 to 2011-Methods and results. Environ. Chem. 2013, 10, 102-110. [CrossRef]

38. Kentisbeer, J.; Leeson, S.; Malcolm, H.; Leith, I.; Braban, C.F.; Cape, J.N. Patterns and source analysis for atmospheric mercury at Auchencorth Moss, Scotland. Environ. Sci. Process. Imp. 2014, 16, 1112-1123. [CrossRef] [PubMed]

39. Brown, R.J.C.; Goddard, S.L.; Butterfield, D.M.; Brown, A.S.; Robins, C.; Mustoe, C.L.; McGhee, E.A. Ten years of mercury measurement at urban and industrial air quality monitoring stations in the UK. Atmos. Environ. 2015, 109, 1-8. [CrossRef]

40. Ebinghaus, R.; Jennings, S.G.; Kock, H.H.; Derwent, R.G.; Manning, A.J.; Spain, T.G. Decreasing trends in total gaseous mercury in baseline air at Mace Head, Ireland from 1996 to 2009. Atmos. Environ. 2011, 45, 3475-3480. [CrossRef]

41. Wängberg, I.; Nerentorp-Mastromonaco, M.G.; Munthe, J.; Gårdfeldt, K. Airborne mercury species at the Raö background monitoring site in Sweden: Distribution of mercury as an effect of long-range transport. Atmos. Chem. Phys. 2016, 16, 13379-13387. [CrossRef]

42. Kock, H.-H.; Bieber, E.; Ebinghaus, R.; Spain, T.G.; Thees, B. Comparison of long-terms and seasonal variations of atmospheric mercury concentrations at the two European costal monitoring stations Mace Head, Ireland, and Zingst, Germany. Atmos. Environ. 2005, 39, 7549-7556. [CrossRef]

43. Li, J.; Sommar, J.; Wangberg, I.; Lindqvist, O.; Wei, S.Q. Short-time variation of mercury speciation in the urban of Göteborg during GÖTE-2005. Atmos. Environ. 2008, 42, 8382-8388. [CrossRef]

44. Albuquerque, M.; Coutinho, M.; Rodrigues, J.; Ginja, J.; Borrego, C. Long-term monitoring of trace metals in PM10 and total gaseous mercury in the atmosphere of Porto, Portugal. Atmos. Pollut. Res. 2017, 3, 535-544. [CrossRef]

45. Stamenkovic, J.; Lyman, S.; Gustin, M.S. Seasonal and diel variation of atmospheric mercury concentrations in the Reno (Nevada, USA) airshed. Atmos. Environ. 2007, 31, 6662-6672. [CrossRef]

46. Lyman, S.N.; Gustin, M.S. Determinants of atmospheric mercury concentrations in Reno, Nevada, USA. Sci. Total Environ. 2009, 408, 431-438. [CrossRef] [PubMed]

47. Gay, D.A.; Schmeltz, D.; Prestbo, E.; Olson, M.; Sharac, T.; Tordon, R. The atmospheric mercury network: Measurement and initial examination of an ongoing atmospheric mercury record across North America. Atmos. Chem. Phys. 2013, 13, 11339-11349. [CrossRef]

48. Cheng, I.; Zhang, L.; Mao, H.; Blanchard, P.; Tordon, R.; Dalziel, J. Seasonal and diurnal patterns of speciated atmospheric mercury at a coastal-rural and a coastal-urban site. Atmos. Environ. 2014, 82, 193-205. [CrossRef]

49. Xu, L.; Chen, J.; Yang, L.; Niu, Z.; Tong, L.; Yin, L.; Chen, Y. Characteristics and sources of atmospheric mercury speciation in a coastal city, Xiamen, China. Chemosphere 2015, 119, 530-539. [CrossRef]

50. Nie, X.; Wang, Y.; Mao, H.; Wang, T.; Li, T.; Wu, Y.; Li, Y.; Hou, C.; Qie, G.; Feng, X.; et al. Atmospheric mercury in an eastern Chinese metropolis (Jinan). Ecotoxicol. Environ. Safety 2020, 15, 110541. [CrossRef]

51. Zhang, H.; Wang, Z.; Wang, C.; Zhang, X. Concentrations and gas-particle partitioning of atmospheric reactive mercury at an urban site in Beijing, China. Environ. Pollut. 2019, 249, 13-23. [CrossRef]

52. Yin, X.; Zhou, W.; Kang, S.; de Foy, B.; Yu, Y.; Xie, J.; Sun, S.; Wu, K.; Zhang, Q. Latest observations of total gaseous mercury in a megacity (Lanzhou) in northwest China. Sci. Total Environ. 2020, 720, 137494. [CrossRef] 
53. Han, Y.-J.; Kim, J.-E.; Kim, P.-R.; Kim, W.-J.; Yi, S.-M.; Seo, Y.-S.; Kim, S.-H. General trends of atmospheric mercury concentrations in urban and rural areas in Korea and characteristics of high-concentration events. Atmospheric Environ. 2014, 94, 754-764. [CrossRef]

54. Kim, K.-H.; Brown, R.J.C.; Kwon, E.; Kim, I.-S.; Sohn, J.-R. Atmospheric mercury at an urban station in Korea across three decades. Atmos. Environ. 2016, 131, 124-132. [CrossRef]

55. Lyman, S.N.; Gustin, M.S. Speciation of atmospheric mercury at two sites in northern Nevada, USA. Atmospheric Environ. 2008, 42, 927-939. [CrossRef]

56. Czaplicka, M.; Pyta, H. Transformations of mercury in processes of solid fuel combustion-Review. Arch. Environ. Prot. 2017, 43, 82-93. [CrossRef]

57. Castilhos, Z.; Rodrigues-Filho, S.; Cesar, R.; Rodrigues, A.P.; Villas-Bôas, R.; de Jesus, I.; Lima, M.; Faial, K.; Miranda, A.; Brabo, E.; et al. Human exposure and risk assessment associated with mercury contamination in artisanal gold mining areas in the Brazilian Amazon. Environ. Sci. Pollut. Res. Int. 2015, 22, 11255-11264. [CrossRef] [PubMed]

58. Nakazawa, K.; Nagafuchi, O.; Kawakami, T.; Inoue, T.; Yokota, K.; Serikawa, Y.; Cyio, M.; Elvince, R. Human health risk assessment of mercury vapor around artisanal small-scale gold mining area, Palu city, Central Sulawesi, Indonesia. Ecotox. Environ. Safety 2015, 124, 155-162. [CrossRef] [PubMed]

59. Fang, G.-C.; Chen, Y.-C.; Lo, C.-T.; Cho, M.-H.; Zhuang, Y.-J.; Tsai, K.-H.; Huang, C.-Y.; Xiao, Y.-F. Concentrations and analysis of health risks of ambient air metallic elements at Longjing site in central Taiwan. Environ. Geochem. Health 2018, 40, 461-472. [CrossRef]

60. Moreda-Piñeiro, J.; Rodríguez-Cabo, A.; Fernández-Amado, M.; Piñeiro-Iglesias, M.; Muniategui-Lorenzo, S.; López-Mahía, P. Levels and sources of atmospheric particle-bound mercury in atmospheric particulate matter (PM10) at several sites of an Atlantic Coastal European Region. Atmosphere 2019, 11, 33. [CrossRef]

61. Nazarpour, A.; Ghanavati, N.; Watts, M.J. Spatial distribution and human health risk assessment of mercury in street dust resulting from various land-use in Ahvaz, Iran. Environ. Geochem. Health 2018, 40, 693-704. [CrossRef]

62. Xu, H.; Wang, Y.; Liu, R.; Wang, M.; Zhang, Y. Spatial distribution, chemical speciation and health risk of heavy metals from settled dust in Qingdao urban area. Atmosphere 2019, 10, 73. [CrossRef]

(C) 2020 by the authors. Licensee MDPI, Basel, Switzerland. This article is an open access article distributed under the terms and conditions of the Creative Commons Attribution (CC BY) license (http://creativecommons.org/licenses/by/4.0/). 